\title{
FUNGAL BIOMASS, PRODUCTION AND SPORULATION ASSOCIATED WITH PARTICULATE ORGANIC MATTER IN STREAMS
}

\author{
M. O. Gessner \\ Limnological Research Center, Swiss Federal Institute for Environmental Science and Technology (EAWAG), 6047 Kastanienbaum, \\ Switzerland.
}

Keywords: Aquatic hyphomycetes, bacteria, biomass, decomposition, leaf litter, mycelial growth, POM, production, sporulation, stream, wood.

\section{SUMMARY}

Current evidence indicates that fungi in streams are essentially restricted to coarse particulate organic matter such as decomposing leaf litter and wood. As the size of organic particles decreases, the proportion of fungal biomass also decreases. In coarse particulate organic matter, fungal biomass can be substantial, in some streams exceeding $15 \%$ of the total detrital mass in relatively labile types of leaf litter. Aquatic hyphomycetes are the predominant fungi occurring in this habitat. In all direct comparisons between leaf-associated fungi and bacteria which have been carried out to date, fungal biomass greatly exceeded bacterial biomass, typically accounting for more than $95 \%$ of the total microbial biomass. Maximum growth rates of fungi have been found to vary from 0.02 to 0.2 day $^{-1}$, indicating, in combination with the high fungal biomass in leaves, that a substantial leaf-associated production occurs in streams. Like biomass, fungal production also exceeded that of bacteria in the two comparative studies published to date. A significant portion of thic fungal production is eventually liberated as conidia. Up to $7.5 \times 10^{6}$ conidia, corresponding to about $5 \mathrm{mg}$, have been found to be released per $\mathbf{g}$ of leaf litter per day. However, considerable differences in leaf-associated sporulation and fungal biomass exist between different leaf species and streams. Correlational evidence suggests that the development of fungi in leaf litter is controlled by both the nutrient concentration in stream water and leaf quality, as determined by the concentration of refractory leaf constituents such as lignin. Fungal activity may in turn control the breakdown rate of leaf litter. The annual leaf-associated production of fungi determined in a headwater stream ( $34 \mathbf{g}$ dry mass per $\mathbf{m}^{2}$ of stream bed) agrees well with the result of a rough calculation that is based on average leaf inputs to streams, leaf retention efficiencies at base flow and estimated fungal biomass in decomposing leaves. Both figures are also well in the range of estimates obtained for macroinvertebrate production in streams. Taken together, the presented evidence thus points to a central role for fungi in stream ecosystems. With the suite of methods now available, adequate consideration of these organisms in stream ecology should be facilitated in the future.

\section{INTRODUCTION}

Fungi are a rather neglected group of organisms, especially when it comes to assessing their roles in natural ecosystems. Reasons for this fact are probably manifold but appear to include a traditional lack of interest by biologists, the ensuing underdeveloped status of taxonomy, and the methodological difficulties associated with the study of mycelial growth forms in opaque solid substrates. In ctreams, however, as in a few other systems, fungi have been recognized as an important component of the ecosystem (BARLOCHER, 1992a; SUBERKROPP, 1998). In large parts this appears to be due to KAUSHIK \& HYNES' (1971) pioneering and comprehensive study on leaf litter breakdown in a Canadian low-order stream, in

Limnetica, 13 (2): 33-44 (1997)

J. Pozo \& A. Elosegi (eds)

Proceedings of the European Meeting on Litter Breakdown in Rivers and Stream

(1) Asociación Española de Limnología. Madrid, Spain which fungi were considered to be important participants. In addition, subsequent work on leaf-litter fungi in streams by $F$. Bärlocher, K. Suberkropp and others has been successful in bridging the gap between mycology and general stream ecology (BARLOCHER \& KENDRICK, 1974; SUBERKROPP \& KLUG, 1976; BARLOCHER, 1992a; SUBERKROPP, 1992, 1998), an achievemerit that is reflected in many contributions to this Special Issue.

The most prominent and currently best known fungi in streams are the so-called aquatic hyphomycetes (INGOLD, 1942) or Ingoldian fungi (BARLOCHER, 1992a). Although a range of other fungi are regularly found in streams on different types of substrata (MALTBY, 1992), e.g. diverse acsemblages of ascomycetec on woody debris (SHEARER, 1993), aquatic 
hyphomycetes are those streain fungi which typically occur in association with decomposing leaf litter. The relative ease with which inany aquatic hyphomycetes can be recognized is due to their characteristic conidia aiid often allows ctraightforward species identificatioii iii field samples. Culturing or nucleic acid based techniques, now popular elsewhere in microbial ecology (e.g., AMANN et al.. 1995: FELL \& NEWELL. 1997: STAHL. 1997), are therefore not generally required for studying aquatic hyphoniycete assemblages in their natural environnient.

In addition to identifying the organisms present in a habitat. consideration of their productivity is essential to address many ecological issues. The term productivity is used here synonymoucly with average production rate over some extended period of time in a defined cystem. As productivity is one critical component that determines the fitness of organisms, it is a fundamental parameter in investigations relating to evolutionary aspects of ecology. Biological production also constitutes a major flux of carbon and nutrientc in ecosystemc and therefore needs to be taken into account in food-web and system-oriented ecological studies. Lastly, productivity can sometimes be used as a surrogate for organismic activity in ecosystems, because a high productivity generally results from high activity. This makec biological productivity a useful parameter also in process-oriented studiec. Thus, knowledge about organismic productivity is of prime iniportance in all broad areas of eco$\log y$.

The main purpose of this article is to summarize the quantitative evidence available today, 27 years after KAUSHIK \& HYNES' (1971) seminal paper, indicating that fungi are most prevalent iii streamc and fulfil critical functions in these ecosysteinc. Specifically, I will review estimates of fungal biomass. growth and production in, and sporulation of aquatic hyphomycetes on, decomposing leaf litter. Before gctting into this main theme, I will briefly coininent on some basic inethodological aspects of biomas: determinations in litter-associated fungi. Additionally, 1 will present correlational evidence relating fungal productivity to leaf litter quality and breakdown rate, and also include simple model calculations and further empirical evidence demonstrating the critical contribution of fungi to overall stream ecosystem structure and function.

\section{FUNGAL BIOMASS}

\section{Some basic methodological considerations}

A detailed discussion of the methods used for determining fungal biomasc and production associated with particulate organic matter (POM) in streams is beyond the scope of this paper.
Coniprehensive accounts are given by NEWELL (1992) and GESSNER \& NEWELL (1997). The methods most frequently used to estiinate the bioniass of fungi in litter include determination of hyphal hiovolume. quantification of selected cell constituents such as chitin. ergosterol and ATP. and immunological methods, all of which except the chitin method have been applied to fungi associated with leaf litter in streams. Other inethodc, including nucleic acid based technologies, are conceivable. but to my knowledge no specific technique has been proposed and tested in streams.

Quantification of ergosterol is currently considered to be the best method when the total living hiomass of fungi is to he determined (NEWELL 1992; GESSNER \& NEWELL. 1997), but it does not allow determination of the biomass of individual species within a fungal assemblage. Immunological techniques have the potential to fill this gap (BERMINGHAM et al.. 1995a. 1996. 1997; NEWELL, 1992). Whichever method is favoured by individual researchers. it must be borne in mind that all of them suffer from shortcomings. This restricts the use of these methods to controlled or well-known systems, comparative studies, and studies that do not critically rely on very precise measurements. Often, however, at least one of thece criteria applies to ecological investigations.

The discussion of advantages and shortcomings of methodc for determining fungal biomasc centers on imperfect analytical techniques and the potential variability in the conversion factors required for all methodc. There is, however. also a conceptual component to the issue, which appears to have been neglected (but see e.g., FRANKLAND, 1975):Filamentous fungi grow as self-extending tubes thereby permanently concentrating cytoplasm in hyphal tips (e.g., KOCH, 1994). As distance from the tips increasec, the vitality of hyphal cections decreases until "ghost hyphae" devoid of cytoplasm result and hyphae even fragment (FRANKLAND, 1975; COOKE \& RAYNER, 1984). At which point along this continuum would one consider a hyphal cection to be fungal hiomass? At which point would one coiicider that a hyphal cection ceases to be fungal hiomass and becomes dead organic matter of fungal origin?

Different methods to determine fungal biomass are targetcd against hyphae with a different status along this continuum. Chitin. for example, ic a quite refractory cell wall component. Consequently, it will persist even after cell death. Results of the chitin assay are likely, therefore, to reflect the total mycelial mass present in a sample, making litte or no distinction between dead and actively inetabolizing portions (NEWELL et al.. 1989; NEWELL. 1992). Methods based on the determination of hyphal length fall basically in the same category, unless an effort is inade to distinguish betweeii hyphae of different 
metabolic status. With immunological methods, the position along the vitality gradient depends on the antigen against which antibodies have been raised. When cell wall carbohydrates are involved. it is likely that total mycelial mass is measured as with the chitin assay. ATP measurements are positioned on the opposite end of the continuum. As the general "currency" of metabolic processes, ATP is quickly turned over and. to soine extent, is related to the physiological status oí an organism (KARL, 1980: POULICEK \& DANCKERS, 1995). Some of the common methods for determining microbial biomass in soil, especially the subctrate induced respiration (SIR) method, represent an extreme in this respect in that it is directly based on an activity measurement. Biomass determiiiations based on the quantification of ergosterol are likely to lie somewhere in between the extremes. Ergosterol is cheniically quite labile and the bulk of the molecule is membrane-bound, experiencing a more rapid turnover than a macromolecular cell wall constituent such as chitin while still exerting a structural fiinction (table 1). In view of these fundamental differences between methods, it would appear that deviating results in comparative studies need not be due to methodological insufficiencies. Instead, they inay reflect intrinsic differences that provide the opportunity for operationally defining biomass along the continum reaching from highly vital to dead hyphal sections.

\section{Habitats of saprotrophicfungi in streams}

The conventional opinion is that growth of fungi in streams is mainly associated with coarse particulate organic inatter
(CPOM) cuch as leaf litter and wood, but studies that have tested this hypothesis are scarce. As one possible way to approach this question, SINSABAUGH et al. (1991) iised the ergosterol method to assess in which compartments, or habitats, of a stream, fungi build up a significant biomass. On submerged glass slides, fungal biomass was found to be more than 50 times lower than on standardized wood blocks exposed in a ctream at the saine time and location, suggesting a minor presence of fungi in biofilms on mineral surfaces but a copious colonization of woody debris in this stream. When expressed per unit surface area. ergosterol was even more important in wood than in much less refractory leaf litter (GOLLADAY \& SINSABAUGH, 1991). This finding is in line with the maximum concentration of fungal biomass (36 $\mathrm{mg} \mathrm{g}^{-1}$ AFDM) found in decomposing wood veneer strips submerged in a stream (TANK et al., 1998), which approach those found in leaf litter (see below). In organic matter naturally deposited on the stream bed, ergosterol concentrations show an increasing trend with increasing particle size (SINSABAUGH et al.. 1992), a finding that has been confirmed by SINSABAUGH \& FINDLAY (1995) for a tidal freshwater system, and by H. CAI et al. (unpublished data) for POM collected froin both surface sediments and the hyporheic zone of a stream in Switzerland. Thus, unlike bacteria which are ubiquitous in aquatic environinents, ergosterol-containing fungi indeed appear to have their main habitat in coarse particulate organic matter (СРOM). Further studies are needed, however. to explore whether thic conclusion holds generally and whether specific types of CPOM other than woody debris and leaf litter (e.g., bark, cones, macrophyte tissue) are also conducive to substantial fungal biomass accumulation.

Table 1. Features of ergosterol that are advantageous for an index molecule of fungal biomass.

$\begin{array}{ll}\text { Feature } & \text { Utility } \\ \text { Mestriction essentially to higher fungi } & \begin{array}{l}\text { Ensures specificity for most practical considerations } \\ \text { Probably indicates living biomass, because compartmenta- } \\ \text { tion by membranes is critical for maintaining cell functions } \\ \text { Conceivahly results in destruction of the molecule soon } \\ \text { after cell death, thus indicating living biomass }\end{array} \\ \begin{array}{l}\text { Relative constancy of mycelial concentrations } \\ \text { within and between species }\end{array} & \begin{array}{l}\text { Allows reasonably accurate estimates when biomass is to } \\ \text { be reported in terins of fungal dry mass, carbon, or a simi- } \\ \text { lar parameter }\end{array} \\ \text { Absorbance at } 282 \mathrm{~nm} & \begin{array}{l}\text { Facilitates analytical detection and discrimination from } \\ \text { potentially interfering plant and animal sterols }\end{array}\end{array}$




\section{Dynamics of fungal biomass in decomposing leaf litter}

Leaf litter is the most abundant and accesible source of CPOM in woodland streams (e.g., WEBSTER et al., 1995) and, among all types of CPOM, has attracted most interest in studies on fungal biomass dynamics. Fig. 1 shows the typical pattern of change of ergosterol concentrations (i.e., fungal biomass) as it is commonly observed in leaves that decompose in streams. Freshly shed leaves contain no ergosterol or only minor amounts. Suhsequently, there is a rapid increase typically within a few weeks after leaves have entered a stream, resulting in maximum concentrations relatively early during the breakdown sequence, i.e. before half of the initial leaf mass is lost. In later breakdown stages, ergosterol concentrations level off or decrease, the extent depending on the leaf species and the individual stream examined. These results strongly support the early contention (SUBEKROPP \& KLUG, 1976) that fungi dominate the microbial decomposer assemblages during the initial stages of leaf litter breakdown in streams.

PAUL \& MEYER (1996) reported the only notable exception to the described general pattern. In yellow poplar (Liriodendron tulipifera) leaves, these authors observed a substantial fungal biomass accumulation even before leaves were submerged, a rapid further increase immediately after immersion (i.e., within two days), and a subsequent gradual decrease eventually resulting in rather low levels (i.e., less than one quarter of the maximum). The most plausible explanation for this unusual pattern is that the leaf litter used in experiments was heavily colonized by fungi before immersion, a boost of

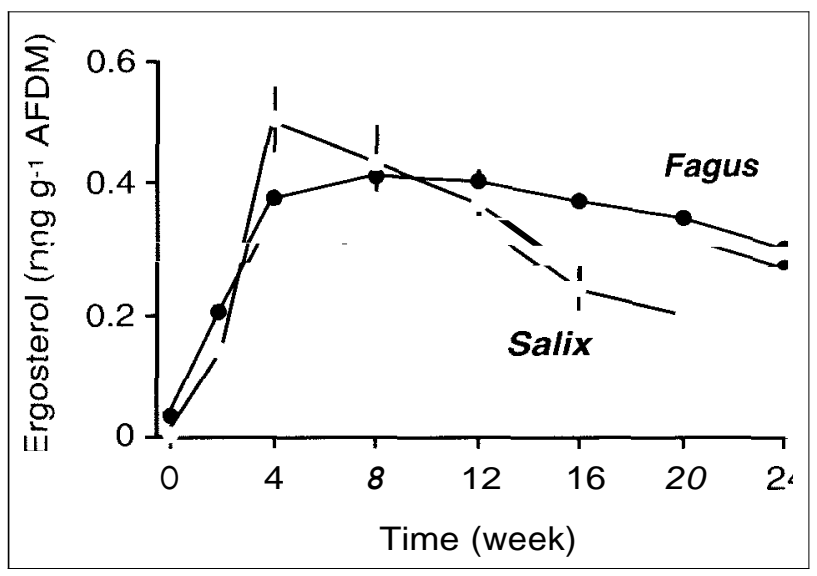

Figure 1. Dynamics of ergosterol concentrations in beech (Fagus sylvatica) and willow (Salix alba) leaves decomposing in a softwater mountain stream and a seventh-order river, respectively (after GESSNER \& CHAUVET, 1994, and BALDY et al., 1995). Vertical bars represent \pm 1 standard deviation. growth when the water supply became unlimited after submergence in the stream, but the subsequent failure to cope with the abiotic and/or biotic conditions imposed on the putative terrestrial fungi in the aquatic environment.

\section{Maximum fungal biomass in decomposing leaf litter}

Ergosterol concentrations are a relative measure of fungal biomass, which is useful for comparative purposes but insufficient if, for example, the quantitative importance of fungi in ecosystems is to be assessed. Consequently, conversion factors are required which relate amounts of ergosterol to fungal biomass in terms of carbon, dry mass, or a similar parameter. To establish such conversion factors, GESSNER \& CHAUVET (1993, 1994) and SUBERKROPP et al. (1993) analysed a total of 14 species of aquatic hyphomycetes and found mycelial ergosterol concentrations to vary hetween 2.3 and $11.5 \mathrm{mg} \mathrm{g}^{-1}$ mycelial dry mass, with an average of about $5.5 \mathrm{mg} \mathrm{g}^{-1}$. This average value is higher than some previously determined concentrations, but remarkably similar to concentrations determined for ascomycetous salt-marsh and mycorrhizal fungi (ANTIBUS \& SINSABAUGH, 1993; NEWELL, 1996; GESSNER \& NEWELL, 1997; FELL \& NEWELL, 1997), suggesting that fungi maintain their ergosterol concentrations within a relatively narrow range, a necessary requirement for a reliable index molecule of fungal biomass. BERMINGHAM et al. (1995b) have yuestioned the relative constancy (i.e., a range ofabout 1:5) of mycelial ergosterol concentrations, but because of the use of apparently unsatisfactory experimental and analytical procedures coupled with the notably erratic results obtained in that study, the "critica1 assessment" by BERMINGHAM et al. (1995b) is, in my opinion, of doubtful value ( $s e e$ also FELL \& NEWELL, 1997).

If we accept the estimates of mycelial ergosterol concentrations determined by GESSNER \& CHAUVET (1993), the biomass of fungi associated with decomposing leaf litter in streams can be estimated in terms of mycelial dry mass or ash-free dry mass (table 2). Ivfore accurate estimates can be vinaincú when fungal community structure is known and species-specific conversion factors are applied. This is often possible with aquatic hyphomycete assemblages, provided that the sporulating species also constitute the mycelial biomass within leaves (GESSNER \& CHAUVET, 1993). With this approach, fungal biomass in decomposing leaves has been found to attain a maximum of $15.5 \%$ of the total detrital dry mass in ash (Fraxinus excelsior) leaves decomposing in a coftwater Pyrenean stream (GESSNER \& CHAUVET, 1994), and a similarly high biomass is calculated for yellow poplar leaves decomposing in hardwater streams in the southern United States (SUBERKROPP et al., 
Table 2. Estiniates of niaximum fungal biomass asaociated with decomposing leaf litter in streams as deduced frorn ergosterol, ATP and hyphal biovolume determinations, and an immunoassay. Literature data reported on an aerial basis (e.g., per cm ${ }^{2}$ of leaf surface area) are not considered in this compilation. Ergosterol fungal biomass is expressed either as mg rnycelial dry mass per g of detrital dry mass, as ing mycelial ash-free dry mass (AFDM) per g of detrital AFDM, or as ing mycelial carbon per $\mathrm{g}$ of detrital carbon, all three modes of expression being interchangeable when the ash and carbon contents of the mycelium and detrital masa are the same. Unless species-specific conversion factors were available, ergosterol fungal biomass was calculated based on a mycelial ergosterol concentration of $5.5 \mathrm{mg} \mathrm{g}^{1}$ dry mass (GESSNER \& CHAUVET, 1993; GESSNER \& NEWELL, 1997), or of 6.0 mg g ${ }^{\prime}$ AFDM, i.e. assuming a mycelial ash content of $8 \%$. ATP fungal biomass was calculated based on the assumptions that $90 \%$ of the total ATP pool was fungal (see table 3). that the mycelial ash content was 8\%. and an average ATP concentration of 1.75 mg $g^{\prime}$ inycelial dry mass (SUBERKROPP, 1991; SUBERKROPP et al., 1993). Fungal biomass derived from hyphal length rneasurements was calculated based on an assumed average hyphal diameter ot

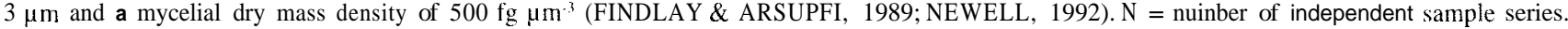
$\mathrm{ATP}=$ adenosine 5 '-triphosphate. ELISA = enzyme-linked immunosorbent assay.

\begin{tabular}{|c|c|c|c|c|c|}
\hline Method & Streams & Leaf species & $\mathrm{N}$ & Fungal biomass (mg $\left.g^{1}\right)$ & Reference \\
\hline Ergoiterol & 1 & 1 & 1 & 84 & GESSNER \& SCHWOERBEL (199I) \\
\hline Ergosterol & 1 & 1 & 7 & $56-105$ & GESSNER et al. (1993) \\
\hline Ergosterol & 2 & 2 & 2 & $127-170$ & SUBERKROPP et al. (1993) \\
\hline Ergoiterol & 1 & 7 & 7 & $61-155^{1}$ & GESSNER \& CHAUVET (1994) \\
\hline Ergoiterol & 4 & 2 & 8 & $1.1-1.7$ & GRIFFITH \& PERRY ( 1994) \\
\hline Ergosterol & $\mathbf{B}$ & 3 & 3 & $50-99$ & BALDY et al. (1995) \\
\hline Ergorterol & & 1 & 3 & $40-164 "$ & SUBERKROPP (1995) \\
\hline Ergosterol & 1 & 4 & 6 & $4.5-25$ & MAHARNING \& BARLOCHER (1996) \\
\hline Ergoiterol & 2 & 3 & 6 & $3.3-102$ & PAUL \& MEYER (1996) \\
\hline Ergosterol & 2 & 1 & 2 & $34-125^{\prime \prime}$ & WEYERS \& SUBERKROPP (1996) \\
\hline Ergoiterol & 1 & 1 & 1 & 14 & BALDY \& GESSNER (1997) \\
\hline Ergosterol & 1 & 1 & 1 & 16 & GESSNER \& CHAUVET ( 1997) \\
\hline Ergoiterol & 1 & 1 & 1 & $41-81^{h}$ & SUBERKROPP (1997) \\
\hline Ergoaterol & 1 & 1 & 14 & $31-73$ & FABRE \& CHAUVET (1998) \\
\hline Ergoiterol & 3 & 2 & 6 & $26-65$ & POZO etal. (1998) \\
\hline ATP & 1 & 2 & 2 & $34-92$ & SUBERKROPP \& KLUG (1976) \\
\hline ATP & 4 & 3 & 24 & $16-120$ & ROSSET et al. (1982) \\
\hline ATP & 2 & 2 & 4 & $19-78$ & MEYER \& JOHNSON (1 983) \\
\hline ATP & 1 & 1 & 1 & 136 & LAWSON et al (1984) \\
\hline ATP & 2 & 1 & 2 & $7.3-30$ & SUBERKROPP (1991) \\
\hline ATP & 2 & 2 & 2 & $49-85$ & SUBERKROPP ef al (1993) \\
\hline ATP & 1 & $B$ & 2 & $26-27$ & HOWE \& SUBERKROPP (1994) \\
\hline ATP & 3 & & 9 & $2.4-12$ & GRIFFITH et al. (1995) \\
\hline ATP & 2 & 1 & 2 & $28-63$ & JENKINS \& SUBERKROPP (1995) \\
\hline ATP & 8 & 1 & 10 & $15-103$ & SUBERKROPP \& CHAUVET (1995) \\
\hline ATP & 3 & 3 & 18 & $0.0002-0.0012$ & MEEGAN et al. (1996) \\
\hline ATP & 3 & 3 & 18 & $0.0002-0.0022$ & ROWE et al. (1996) \\
\hline Biovolume $^{d}$ & 1 & 1 & 1 & 0.12 & IVERSEN (1973) \\
\hline Biovolume & 1 & 1 & 1 & 0.7 & BARLOCHER \& KENDRICK (1974) \\
\hline Biovolume & 1 & 3 & 6 & $13-21$ & BUTTIMORE et al (1984) \\
\hline Biovolume & 1 & 3 & 3 & $8-49$ & FINDLAY \& ARSUFFI ( 1989) \\
\hline ELISA & 1 & 1 & 1 & $>6.7^{t}$ & BERMINGHAM et al. (1997) \\
\hline
\end{tabular}

Species-specific conversion factors applied to all or part of the data.

Leaves randonily collected froni the stream bed at eleven ozcasions throughout $u$ year.

Values suspicious; compare GRIFFITH et al. (1995), who worked in the same streams.

"Hyphal length determined after clearing of whole leaves.

Hyphal length determined after grinding and collecting leaf pieces on membrane filters.

'Assuming that mycelial dry masa was $10 \%$ of wet mass; only three of twelve or more species present in samples were considered.

1993: SUBERKROPP. 1995). Considerably lower concentrations have also been noted, however (table 2). Similar inferences can be made based on biomass estimates derived from ATP determinations. where some maxirnum values in leaf litter again exceed $10 \%$ of the total detrital mass (table 2 ). Furthermore. as with ergosterol concentrations. a considerable 
variability in maxiinum fungal biomass is apparent both within and between different studies that used ATP as a measure of microbial (i.e. mainly fungal) biomass.

In 1973, IVERSEN first attempted to quantify the biomass of fungi associated with decomposing leaves in a Danish loworder stream. The techniyue used in that study consisted in determining hyphal length and biovolume after clearing of beech (Fagus sylvatica) leaves with chloral hydrate. The maximum biomass calculated from the data of that study is about $0.012 \%$ of the total detrital mass (GESSNER et al., 1997). leading IVERSEN (1973) to conclude that fungi were not a quantitatively important coinponent of the system he studied. Comparison of this early, rather influential (e.g. BOULTON \& BOON, 1991) value with the data compiled in table 2 reveals. however, that IVERSEN's (1973) estimate was exceedingly low, e.g. 500 times lower than the bioinasc found in the same type of leaf litter with the ergosterol technique, albeit in a different ctreain (fig. 1). From a coastal marine decomposition systein it is known that ineasurements of hyphal length after clearing of leaves result in a substantial underestimation of fungal bioinass (NEWELL, 1992), suggesting that IVERSEN's (1973) original conclusion that fungi are unimportant in his study system inight have been incorrect. Based on biomacs estimates derived from ergosterol concentrations (table 2), one would draw the opposite conclusion, namely that fungi are an extremely important coinponeni of the leaf litter-microbe complex in streains. It appears, thuc, that some of the very low estimates of fungal biomass reported in the literature are attributable to the use of inadequate methods.

Some of the variability manifect in table 2 is not related to methodological problems, but clearly reflectc real differences betweeii different streams and leaf species. This point can be illustrated with data derived from both ergosterol and ATP concentrations. GESSNER \& CHAUVET (1994), for example, found large differences in the fungal biomass accumulating in ceven species of leaves expoced siinultaneously in a sofwater stream (table 2), while SUBERKROPP \& CHAUVET (1995) obcerved similarly large differences in a single leaf species exposed in eight streams differing in water chemictry (table 2).

SUBERKROPP \& CHAUVET (1995) chowed that the between-stream differences may be related to nutrient availability in the water flowing across the decomposing leaves (fig. 2a). The biomacs of fungi that accumulated in cubmerged yellow poplar leaves was found to be pocitively correlated with the nutrient concentration in the stream water. Similarly, differences in fungal biomass may be related to leaf quality. For example, GESSNER \& CHAUVET (1994) noted a significant negative correlation between the initial lignin content of different

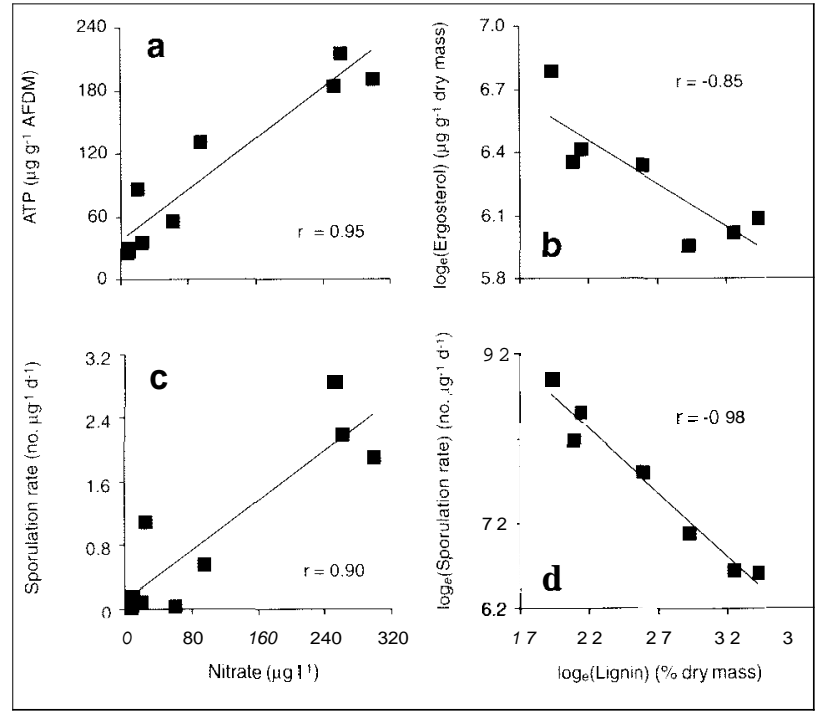

Figure 1. Relationships hetween the nutrient concrniration $(\mathrm{a}, \mathrm{c})$ of streuin water and lignin concentration of leaves (b, d), and the fungal biomass and sporulation associated with decomposing leaves in streams (calculated and drawn after data in GESSNER \& CHAUVET. 1994, and SUBEKKKOPP\& CHAIJVET, 1995).

leaf species (as a measure of leaf quality) aiid the fungal biomass that accumulated in these leaves (fig. 2b). In both of the above studies, fungal biornass was also positively correlated with leaf breakdown rate. MAHARNING \& BARLOCHER (1996) obtained similar results in that they also found significaiit positive correlations between fungal biomass and breakdown rate of five types of CPOM. The quantitative relationship in that study differed inarkedly from that obtained by GESSNER \& CHAUVET (1994). This is not curprising, however. given the large variation in fungal biomacs and leaf breakdown rate that SUBERKROPP \& CHAUVET (1995) were able to attribute to the nutrient concentration of stream water, i.e.. to an extcrnal, stream-related driving force. Given the high biomass that fungi can build up in leaves (table 2), these correlations suggest that the rates of leaf breakdown in streams may be controlled to a large extent by fungal activity. Fungal activity, in turn, appears to be strongly related to both internal and external variables such as the concentration of refractory leaf constituents (e.g., lignin) and nutrient availability in the stream water (GESSNER et al., 1997).

\section{Comparison of fungal and bacteria1 biomass in decomposing leaf litter}

There is an ongoing debate as to the importance of bacteria and fungi associated with decompocing leaves in streams. 
Table 3 Fungal proportion of total microbial biomass associated with leat litter decomposing in streams where total microbial biomass refers to the sum of fungal and bacterial biomass $\mathrm{N}=$ number of samples

\begin{tabular}{|c|c|c|c|c|}
\hline Mean & Range & $\mathrm{N}$ & Note & Reterence \\
\hline 88 & $63-96$ & 15 & 3 leaf species, summer & FINDLAY \& ARSUFFI ( 1989) \\
\hline 96 & $88-996$ & 18 & 3 leaf species, large river & BALDY et al (1995) \\
\hline 995 & $97-999$ & $x$ & 2 streams & WEYERS \& SUBERKROPP(1996) \\
\hline 97 & $95-99$ & 4 & summer & BALDY \& GESSNER (1997) \\
\hline
\end{tabular}

Importance relates here to the role of thece microorganisms as both decomposerc and as nutritional resource for the stream detritivorec (shredders) that feed on the decomposing leaf litter with its associated microorgaiiicms. Convincing factual evidence to settle this question has long been lacking, because comparative field studies on fungal and bacterial productivity and activity had not been carried out. However, as a starting point. several recent studies compared the leaf-associated biomass of fungi and bacteria in streams and found that fungi consistently accounted for most of the total microbial (i.e. fungal plus bacterial) biomass (table 3 ). Even in a study by FINDLAY \& ARSUFFI (1989), in which estimates of fungal biomass were based on measurements of hyphal length. a niethod that tends to underestimate fungal mass (NEWELL. 1992), a minimum of $63 \%$ and an average of $X X \%$ of the total microbial biomass was attributable to fungi. Fungi hence clearly outweigh bacteria in their function as nutritional resource to shredders. Bacteria might nevertheless be important in the nutrition of shredders by supplying specific dietary components such as vitaminc (PHILLIPS, 1984), although to iny knowledge evidence to support thic hypothesis is lacking. Whether fungi also outbalance bacteria in terms of litterdegrading activity is not yet clear, because a low biomass of bacteria needc not necessarily be related to a low degradative activity (see also diccussion below)

\section{FUNGAL GROWTH RATE AND PRODUC- TION}

The comparison of fungi and bacteria on a biomass basis neglects the fact that losses by selective feeding of detritivorec, sloughing of cells and other processes may lead to a low biomass acsociated with leaves even if microbial production is high. Therefore, accumulated biomass may not be a good indicator of microbial involvement in litter decomposition. The potentially higher tiirnover of bacteria compared to fungi conceivably could result in an underestimation of bacterial involvement in the process. Thic problem is avoided when instantaneous microbial growth rates are determined together with microbial biomasc, and production is subsequently inferred from thic dynatnic meacurement.

Measuring fungal growth rate and production has become possible by means of the so-called acetate-to-ergosterol method devcioped by NEWELL \& FALLON (1991). The principle of the method consists of following the incorporation of radiolabelled acetate into ergosterol as a quasi-specific cell constituent of eumycotic (i.e., higher) fungi (NEWELL, 1993; FELL \& NEWELL, 1997; CESSNER \& NEWELL, 1997). During growth on ash leaves in a microcosm, thc aquatic hyphomycete. Articulospora tetracladia, achieved a growth rate of up to 0.72 per day (fig. 3a; GESSNER \& CHAUVET, 1997). This is equi-
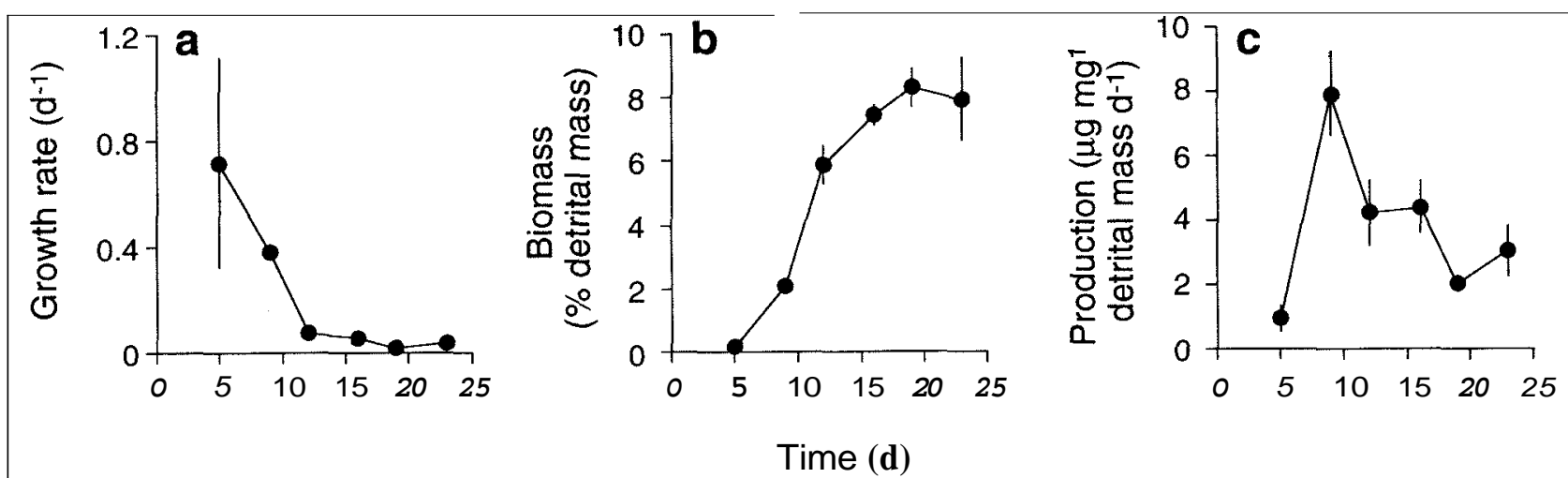

Time (d)

Figure 3. Growth rate (a).biomass (b), and production (c) of ihe aquatic hyphornycete, Articulospora tetracladia, growing on ash leaves in a stream microcosm (modified from GESSNER \& CWAUVET. 1997) Vertical bars represent \pm 1 standard deviation. 
Table 4. Maximum growth rates of fungi associated with decomposing leaf litter in streams, as determined with the acetate-to-ergosterol method. $\mathrm{T}_{\mathrm{d}}=$ doubling time, $\mathrm{N}=$ number of samples.

\begin{tabular}{lrrll}
\hline \hline Growth rate $\left(\mathrm{d}^{\mathrm{l}}\right)$ & $\mathrm{T}_{\mathrm{d}}(\mathrm{d})$ & $\mathrm{N}$ & Note & Reference \\
\hline $0.12-0.20$ & $5-8$ & 21 & yellow poplar leaves, 3 streams & SUBERKROPP (1995) \\
0.086 & 11 & 1 & yellow poplar leaves, hardwater stream & SUBERKROPP \& WEYERS( 1996) \\
0.16 & 6 & 10 & yellow poplar leaves, 2 streams & WEYERS \& SUBERKROPP (1996) \\
0.20 & 5 & 4 & healthy alder leaves, summer & BALDY \& GESSNER (1997) \\
0.017 & 50 & 1 & ash leaves, softwater stream & GESSNER \& CHAUVET (1997) \\
0.070 & 14 & 11 & mixed benthic leaf material, mainly beech & SUBERKROPP (1997) \\
& & & and oak, sampled throughout a year & \\
\hline
\end{tabular}

valent to a daily biomass increment of nearly $80 \%$ of the biomass present, and corresponds to a doubling time of 31 hours, suggesting that, counter to intuition, fungal growth rates might well compare with bacterial growth rates in natural situations.

The highest fungal growth rates in that microcosm study were recorded shortly after fungal occupation of the leaves but then dropped sharply to less than one tenth of the maximum rate (fig. 3a). Fungal biomass was extremely low in the initial phase (fig. $3 b$ ), resulting in a low fungal production in spite of the high growth rate at this time (fig. 3c). During later stages, fungal growth rates remained greater than 0.02 day $^{-1}$, corresponding to doubling times of 13-31 days, even when fungal biomass began to decrease in leaves (day 19 to 23). Table 4 shows that these lower values are more representative of the rates normally seen in field situations; maximum fungal growth rates in leaf material collected from streams range from 0.02 to $0.2 \mathrm{day}^{-1}$. Corresponding doubling times are 5 to 50 days. Although typically much longer than in microcosms, these doubling times are not overly long, and in view of the high fungal biomass in leaves, point to a sizeable fungal production also in the natural stream environment.

In the first published study in which the growth and production of fungi and bacteria was compared in a stream, the maximum bacterial growth rate on submerged leaves was as high as 0.75 day $^{-1}$ (calculated from fig. 4 in WEYERS \& SUBERKROPP, 1996). This rate was nearly four times greater than the highest fungal growth rate (WEYERS \& SUBERKROPP, 1996), and as high as the highest rate found for fungi in microcosms (GESSNER \& CHAUVET, 1997). Under somewhat untypical conditions, a leaf-associated bacterial growth rate of even 5.7 day $^{-1}$ has been measured (BALDY \& GESSNER, 1997). Because of the low bacterial biomass, bacterial production yet remained consistently lower than that of the fungi (BALDY \& GESSNER, 1997). Likewise, in the study by WEYERS \& SUBERKROPP (1996), there was only one case in which the ratio of fungal to bacterial production was lower than one (range of 0.9 to 108). These results are thus qualita- tively similar to the outcome of comparisons between fungi and bacteria on a biomass basis (table 3 ).

SUBERKROPP (1997) has estimated the annual leaf-associated production of fungi in a stream by taking monthly samples of coarse benthic organic matter, in which he determined fungal production rates with the acetate-to-ergosterol method and total organic mass per square meter of stream bed. Through interpolation of the monthly values, he calculated an annual production of $34 \mathrm{~g} \mathrm{~m}^{-2}$ of stream bed. This figure can be compared with a rough estimate deduced from data on leaf litter input to streams, litter retention, and fungal biomass accumulation relative to leaf litter mass loss. If we assume, for example, an annual input of $500 \mathrm{~g}$ leaf litter per square meter of stream bed (WEIGELHOFER \& WARINGER, 1994; WEBSTER et ul., 1995; BENFIELD, 1997), 80\% retention of the litter in the stream channel (note that retention is highly variable depending on geomorphic features and hydrological regimes; JONES, 1997), and a maximum fungal biomass of $100 \mathrm{mg} \mathrm{g}^{-1}$ of leaf mass at a time when $50 \%$ of the leaf litter is broken down (GESSNER \& CHAUVET, 1994; SUBERKROPP \& CHAUVET, 1995; table 2), then leaf-associated fungal production would amount to $20 \mathrm{~g} \mathrm{~m}^{-2}$. SUBERKROPP's (1997) empirical data compare favourably with this rough model calculation. Significantly, both estimates are also well in the range of values normally found for total macroinvertebrate production in streams (BENKE, 1992; WEBSTER et al, 1995), again underscoring the great, and to this point clearly unappreciated, quantitative importance of fungi in stream ecosystems.

\section{SPORULATION}

The picture of fungal productivity associated with organic matter in streams would be incomplete without a consideration of the sporulation activity of aquatic hyphomycetes. Aquatic hyphomycetes can produce more than $7 \times 10^{6}$ conidia per $g$ of leaf litter dry mass per day (table 5), roughly corresponding to 5 $\mathrm{mg} \mathrm{g}^{-1}$ of the litter mass present, or to $10 \%$ of the daily litter 
Table 5. Maximum sporulation rates of aquatic hyphomycetes associated with decomposing leaf litter in streams. All rates are expressed per g detrital AFDM. When the original data are reported in a different format (i.e., per $\mathrm{g}$ detrital dry mass), they were recalculated based on an assumed detrital ash content of $8 \%$. Literature data reported on an areal basis (e.g., per $\mathrm{cm}^{-2}$ of leaf surface area) are not considered in this compilation. $\mathrm{N}=$ number of independent sampie series.

\begin{tabular}{|c|c|c|c|c|c|c|}
\hline $\begin{array}{l}\text { Conidia } \\
\left(\text { no } \mathrm{mg}^{1}{ }^{1} \mathrm{AFDM} \mathrm{d}{ }^{1}\right)\end{array}$ & $\begin{array}{l}\text { Incubation } \\
\text { temperature }\left({ }^{\circ} \mathrm{C}\right)\end{array}$ & $\begin{array}{l}\text { Incubation } \\
\text { period }(\mathrm{h})\end{array}$ & Streams & Leaf species & $\mathrm{N}$ & Reference \\
\hline $600-3000$ & 12 & 48 & 4 & 3 & 12 & BARLOCHER (1982) \\
\hline $1.6-22$ & 20 & 168 & 1 & 2 & 4 & CHAMIER \& DIXON (1982) \\
\hline $940-3060$ & 15 & 48 & 1 & 1 & 7 & BARLOCHER ( 199! ) \\
\hline $170-1270$ & 15 & 24 & 2 & 1 & 2 & SUBERKROPP (1991) \\
\hline $1400-5400$ & 15 & 48 & 1 & 3 & 9 & BARLOCHER (1992b) \\
\hline $860-3670$ & 10 & 48 & 3 & 1 & 6 & CHERGUI \& PATTEE ( 1993) \\
\hline $0.03-50^{\mathrm{a}}$ & & 48 & 1 & 2 & 8 & SRIDHAR \& BARLOCHER (1993a) \\
\hline $0.26-3.4^{b}$ & & 48 & 1 & 1 & 4 & SRIDHAR \& BARLOCHER (1993b) \\
\hline $2200-7800$ & & $24 / 48$ & 2 & 2 & 2 & SUBERKROPP et al (1993) \\
\hline $830-8150$ & 10 & 72 & 1 & 7 & 7 & GESSNER \& CHAUVET (1994) \\
\hline $230-320$ & 15 & 24 & 1 & 1 & 2 & HOWE \& SUBERKROPP (1994) \\
\hline $1200-1450$ & 10 & 72 & 1 & 3 & 3 & BALDY et al. (1995) \\
\hline $4940-8000$ & 15 & 48 & 2 & 2 & 5 & BARLOCHER et al. (1995) \\
\hline $580-1220$ & 15 & 24 & 2 & 1 & 2 & JENKINS \& SUBERKROPP (1995) \\
\hline $63-2900$ & 15 & 24 & 3 & 1 & 3 & SUBERKROPP (1995) \\
\hline $85-2250$ & 15 & 24 & 8 & 1 & 9 & SUBERKROPP \& CHAUVET (199.5) \\
\hline $10-1536$ & 20 & 48 & 1 & 4 & 6 & MAHARNING \& BARLOCHER (1996) \\
\hline $32-35$ & stream & 48 & 2 & 1 & 2 & PAUL \& MEYER (1996) \\
\hline $70-800$ & 15 & 24 & 2 & 1 & 2 & WEYERS \& SUBERKROPP (1996) \\
\hline 217 & 10 & 24 & 1 & 1 & 1 & BALDY \& GESSNER (1997) \\
\hline 57 & 15 & 45 & 1 & 1 & 1 & GESSNER \& CHAUVET (1997) \\
\hline $240-990$ & 10 & 48 & 3 & 2 & 6 & CHAUVET et al. (1997) \\
\hline
\end{tabular}

" One week exposure in stream; only autumn data considered.

${ }^{\mathrm{b}}$ Leaves in advanced decay stage but of indeterminate age.

mass loss (GESSNER \& CHAUVET, 1994). This sporulation activity can result in a conidial concentration exceeding 20,000 per liter of stream water during the period of bulk leaf fall in autumn (e.g., SUBERKROPP, 1991; BARLOCHER, 1992a). At an average conidial mass of $200 \mathrm{pg}$, a conservative estimate (GESSNER \& CHAUVET, 1994; CHAUVET \& SUBERKROPP. 1998), and an assumed stream discharge of $601 \mathrm{~s}^{-1}$, this concentration wouid be equivalent to $10^{11}$ conidia or $20 \mathrm{~g}$ of conidial rnass that pass through a cross section of a small stream per day. On an annual basis, SUBERKROPP (1997) calculated a conidial output of no less than $375 \mathrm{~g}$ dry $\mathrm{m}$ a s for a low-nutrient stream with a base flow of 4-5 $1 \mathrm{~s}^{-1}$.

As with fungal biomass, there is considerable variation in fungal sporulation rates among leaf species and streams (table 5). For example, in the studies conducted by GESSNER \& CHAUVET (1994) and MAHARNING \& BARLOCHER (1996), maximum sporulation rates differed by a factor of 10 and 43 , respectively, on different leaf species, and in the studies by SUBERKROPP \& CHAUVET (1995) and WEYERS \&
SUBERKROPP (1996) rates varied similarly between streamc. The positive correlations between nutrient concentrations in stream water and fungal biomass also holds with sporulation rate (fig. 2c). Likewise, a significant negative correlation was noted between maximum sporulation rate and the initial lignin concentration of different leaf species (fig. 2d). Thus, the data on fungal biomass and sporulation rate lead to consistent conclusions in regard to the activity of aquatic fungi in decomposing leaf litter.

\section{CONCLUSION}

In conclucion, there is a body of quantitative evidence suggecting that fungi, particularly the leaf-associated aquatic hyphomycetes, are most prevalent in streams, where they play an important role in the breakdown of leaf litter. Fungi associated with woody debris are likely to be similarly important, whereas in other stream habitats fungi probably play only minor roles. A number of methods now exist to study saprotrophic 
fungi in aquatic habitats. Although still imperfect in various respects, more widespread application of these methods is likely to result in a thorough understanding of fungal life-history patterns and functions in stream ecosystems.

\section{ACKNOWLEDGEMENTS}

This article is based on a presentation given at the European Meeting on Litter Breakdown in Rivers and Streams held in Septernber 1997 near Bilbao, Spain. 1 am grateful to the organizers for kindly inviting me to attend the conference and for financial support. I also thank E. Chauvet and two anonymous reviewers for critical comments on the manuscript.

\section{REFERENCES}

AMANN, R.I., W. LUDWIG \& K.-H. SCHLEIFER, 1995. Phylogenetic identification and in situ detection of individual microbial cells without cultivation. Microbiol. Rev., 59: 143169.

ANTIBUS, R.K. \& R.L. SINSABAUGH, 1993. The extrac tion and quantification of ergosterol from ectomycorrhizal fungi and roots. Mycorrhiza, 3: 137-144.

BALDY, V., M.O. GESSNER \& E. CHAUVET. 1995. Bacteria, fungi and the breakdown of leaf litter in a large river. Oikos, 74: 93-102

BALDY, V. \& M.O. GESSNER, 1997. Towarda a budget of leaf litter decomposition in a first-order woodland stream. C.R. Acad. Sci. Puris, Science de la vie/Life Sciences. 320: 747-758.

BARLOCHER, F., 1982. Conidium production from leaves and needles in four streams. Can. J. Bot., 60: 1487-1494.

BARLOCHER, F., 1991. Fungal colonization of fresh and dried leaves in the River Teign (Devon, England). Novu Hedwigia, 52:349-357.

BARLOCHER, F., (ed.) 1992a. The ecology of aquatic hyphomycetes, Ecological Studies, Vol. 94, Springer-Verlag, Berlin.

BARLOCHER, F., 1992b. Effects of drying and freezing autumn leaves on leaching and colonization by aquatic hyphomycetec. Freshwat. Biol., 28: 1-7.

BARLOCHER, F. \& B. KENDRICK, 1974. Dynamics of the fungal populationc on leaves in a stream. J. Ecol., 62: 761 791.

BARLOCHER, F., C. CANHOTO \& M.A.S. GRAÇA, 1995. Fungal colonization of alder and eucaiypt leaves in two ctreams in Central Portugal. Arch. Hydrobiol., 133:457-470.

BENFIELD, E.F., 1997. Comparisons of litterfall input to streams. In: Stream organic matter budgets (J.R. WEBSTER \&
J.L. MEYER, edc.): 104-108. J. N. Am. Benthol. Soc., 16:3-161. BENKE, A.C., 1992. Concepts and patternc of invertebrate production in running waters. Verh. Inf. Ver Limnol., 25: 15-38.

BERMINGHAM, S., F.M. DEWEY \& L. MALTBY, 1995a. Development of a monoclonal antibody-based immunoassay for the detection and quantification of Anguillospora longissima colonizing leaf material. Appl. Environ. Microbiol., 61:26062613.

BERMINGHAM, S., L. MALTBY \& R.C. COOKE, 1995b. A critical assessment of the validity of ergosterol as an indicator of fungal biomasc. Mycol. Res., 99: 479-484.

BERMINGHAM, S., L. MALTBY \& F.M. DEWEY, 1996. Monoclonal antibodies as tools to quantify mycelium of aquatic hyphomycetes. New Phytol., 132: 593-601.

BERMINGHAM, S., L. MALTBY \& F.M. DEWEY, 1997. Uxe of immunoassays for the ctudy of natural assemblages of aquatic hyphomycetes. Microb. Ecol., 33: 223-229.

BOULTON, A.J. \& P.I. BOON, 1991. A review of methodology used to measure leaf litter decomposition in lotic environments: time to turn over an old leaf? Aust. J. Mar. Freshwat. Res., 42: 1-43.

BUTTIMORE, C.A., P.W. FLANAGAN, C.A. COWAN \& M.W. OSWOOD. 1984. Microbial activity during leaf decomposition in an Alaskan subarctic stream. Holarct. Ecol. 7: 104110.

CHAMIER, A.-C. \& P.A. DIXON, 1982. Pectinases in leaf degradation by aquatic hyphomycetes I: the field study - The colonization-pattern of aquatic hyphomycetes on leaf packs in a Surrey stream. Oecologia, 52: 109-115.

CHAUVET, E., E. FABRE, A. ElÓSEGUI \& J. POZO, 1997. The impact of eucalypt on the leaf-associated aquatic hyphomycetes in Spanish streamc. Can. J. Bot., 75: 880-887.

CHAUVET, E. \& K. SUBERKROPP, 1998. Temperature sporulation of aquatic hyphomycetes. Appl. Environ. Microbiol., 64: 1522-1525

CHERGUI, H. \& E. PATTEE, 1993. Fungal and invertebrate colonization of Salix fresh and dry leaves in a Moroccan river cyctem. Arch. Hydrobiol., 127: 57-72.

COOKE, R.C. \& A.D.M. RAYNER, 1984. Ecology of saprotrophicfungi. Longman, London.

FABRE, E. \& E. CHAUVET, 1998. Leaf breakdown along an altidudinal ctream gradient. Arch. Hydrobiol., in press.

FELL, J.W. \& S.Y. NEWELL, 1997. Biochemical and molecular methods for the study of marine fungi. In: Molecular approaches to the study of the ocean (K.E. COOKSEY, ed.): 259-283. Chapman \& Hall, London.

FINDLAY, S.E.G. \& T.L. ARSUFFI, 1989. Microbial growth and detritus transformations during decompocition of 
leaf litter in a stream. Freshwat. Biol., 21: 261-269.

FRANKLAND, J.C., 1975. Estimation of live fungal biomass. Soil Biol. Biochem., 7: 339-340.

GESSNER, M.O. \& E. CHAUVET, 1993. Ergosterol-to-biomass conversion factors for aquatic hyphomycetes. Appl. Environ. Microbiol., 59: 502-507.

GESSNER, M.O. \& E. CHAUVET, 1994. lmportance of stream microfungi in controlling breakdown rates of leaf litter. Ecology, 75: 1807-1817.

GESSNER, M.O. \& E. CHAUVET, 1997. Growth and production of aquatic hyphomycetes in decomposing leaf litter. Limnol. Oceanogr., 42: 496-505.

GESSNER, M.O. \& S.Y. NEWELL, 1997. Bulk quantitative methods for the examination of eukaryotic organoosmotrophs in plant litter. In: Manual of environmental microhiology (C.J. HURST, G.R. KNUDSEN, M.J. MCINERNEY, L.D. STETZENBACH \& M.V. WALTER, eds.): 295-308. ASM Press, Washington.

GESSNER, M.O. \& J. SCHWOERBEL, 1991. Fungal biomass associated with decaying leaf litter in a stream. Oecologia, 87: 602-603.

GESSNER, M.O., K. SUBERKROPP \& E. CHAUVET, 1997. Decomposition of plant litter by fungi in marine and freshwater ecosystems. In: The mycota: a treatise on the biology of fungi with emphasis on systems for fundamental and applied research, VolumeIV: environmental and microhial relationships (D.T. WICKLOW \& B. SODERSTROM, eds.): 303322. Springer Verlag, Berlin.

GESSNER, M.O., M. THOMAS, A.M. JEAN-LOUIS \& E. CHAUVET, 1993. Stable successional patterns of aquatic hyphomycetes on leaves decaying in a summer cool stream. Mycol. Res., 97: 163-172.

GOLLADAY, S.W. \& R.L. SINSABAUGH, 1991. Biofilm development on leaf and wood surfaces in a boreal river. Freshwat. Biol.,25: 437-450.

GRIFFITH, M.B. \& S.A. PERRY, 1994. Fungal biomass and leaf litter processing in streams of different water chemistry. Hydrobiologia, 294: 5 1-61.

GRIFFITH, M.B., S.A. PERRY \& W.B. PERRY, 1995. Leaf litter processing and exoenzyme production on leaves in streams of different pH. Oecologia, 102: 460-466.

HOWE, M.J. \& K. SUBERKROPP, 1994. Effects of isopod (Lirceus sp.) feeding on aquatic hyphomycetes colonizing leaves in a stream. Arch. Hydrobiol., 130:93-103.

INGOLD, C.T., 1942. Aquatic hyphomycetes of decaying alder leaves. Trans. Br: Mycol. Soc., 25: 339-417.

IVERSEN, T.M., 1973. Decomposition of autuiiin-shed beech leaves in a cpringbrook and its significance for the fauna.
Arch. Hydrobiol., 72: 305-3 12.

JENKINS, C.C. \& K. SUBERKROPP, 1995. The influence of $\mathrm{pH}$ on the enzymatic degradation of leaf litter in streams. Freshwat. Biol., 33: 245-253.

JONES, J.B., 1997. Benthic organic matter storage in streams: influence of detrital import and export, retention mechanisms, and climate. In: Stream organic matter budgets (J.R. WEBSTER \& J.L. MEYER, eds.): 109-119. J. N. Am. Benthol. Soc. 16: 3-161.

KARL, D.M., 1980. Cellular nucleotide measurementc and applications in microbial ecology. Microbiol. Rev., 44: 739-796.

KAUSHIK, N.K. \& H.B.N. HYNES, 1971. The fate of the dead leaves that fall into streams. Arch. Hydrobiol., 68: 465-5 15.

KOCH, A.L., 1994. The problem of hyphal growth in streptomycetes and fungi. $J$. Theor. Biol., 171:137-1SO.

LAWSON, D.L., M.J. KLUG \& R.W. MERRITT, 1984. The influence of the physical, chemical, and microbiological characteristics of decomposing leaves on the growth of the detritivore Tipula abdominalis (Diptera: Tipulidae). Can. J. Zool., 62: 2339-2343.

MAHARNING, A.R. \& F. BARLOCHER, 1996. Growth and reproduction in aquatic hyphomycetes. Mycologia, 88: 80-88.

MALTBY, L., 1992. Heterotrophic microbes. in: The rivers handbook. Hydrological and ecological principles, Vol. 1 (P. CALOW \& G.E. PETTS, eds.): 165-194. Blackwell, Oxford.

MEEGAN. S.K., S.A. PERRY \& W.B. PERRY, 1996. Detrital processing in streams exposed to acidic precipitation in the Central Appalachian Mountainc. Hydrobiologia, 339: 101-110.

MEYER, J.L. \& C. JOHNSON, 1983. The influence of elevated nitrate concentration on rate of leaf decomposition in a stream. Freshwat. Biol., 13: 177-183.

NEWELL, S.Y., 1992. Estimating fungal biomass and productivity in decomposing litter. In: The fungal community: its organizution and role in the ecosystem, 2 nd ed. (G.C. CARROLL \& D.T. WICKLOW, eds.): 521-561. Marcel Dekker, New York.

NEWELL, S.Y., 1993. Membrane-containing fungal mass and fungal specific growth rate in natural samplec. In: Handhook of methods in aquatic microhial ecology (P.F. KEMP, B.F. SHERR, E.B. SHERR \& J.J. COLE, eds.): $579-$ 584. Lewis Publichers. Boca Raton.

NEWELL, S.Y., 1996. The $\left[{ }^{14} \mathrm{C}\right]$ acetate-to-ergosterol method: factors for conversion from acetate incorporated to organic fungal mass synthesized. Soil Biol. Biochem., 28: 681-683.

NEWELL, S.Y., R.D. FALLON \& J.D. MILLER, 1989. Decomposition and microbial dynamics for standing, naturally positioned leaves of the salt-marsh grass Spartina alterniflora. Mar: Biol., $101: 47$ 1-481. 
NEWELL, S.Y. \& R.D. FALLON. 1991. Toward a method for measuring fungai instantaneous growih rates in fïcld sanples. Ecology, 72: 1547-1559.

PAUL, M.J. \& J.L. MEYER, 1996. Fungal biomass of 3 leaf litter species during decay in an Appalachian stream. J. N. Am. Benthol. Soc. 15: 421-432.

PHILLIPS, N.W.. 1984. Role of different microbes and substrates as potential suppliers of specific, essential nutrients to rnarine detritivoies. Bull. Mar. Sci, 35:283-298.

POULICEK. M. \& V. DANCKERS, 1995. L'ATP et la charge énergétique adénylique (ECA) en écologie microbienne des milieux aquatiques. Océanis, 21: 191-223.

POZO, J.. A. BASAGUREN, A. ELÓSEGUI. J. MOLINERO, E. FABRE \& E. CHAUVET. 1998. Afforestation with Eucalyptus globulus and leaf litter decomposition in streams of northern Spain. Hydrobiologia, 373/374: 101-109.

ROSSET, J.. F. BARLOCHER \& J.J. OERTLI, 1982. Decomposition of conifer needles and deciduous leaves in two Black Forest and two Swiss Jura streams. Int. Rev. ges. Hydrobiol., 67: 695-711

ROWE, J.M., S.K. MEEGAN, E.S. ENGSTROM, S.A. PERRY \& W.B. PERRY. 1996. Comparison of leaf processing rates under different temperature regimes in three headwater streamc. Freshwat. Biol., 36: 277-288.

SHEARER, C.A., 1993. The freshwater Ascomycetes. Nova Hedwigia, 56:1-33.

SINSABAUGH, R.L.. S.W. GOLLADYAY \& A.E. LIN KINS. 1991. Comparison of epilithic and epixylic biofilm developinent in a boreal river. Freshwat. Biol., 25: 179-187.

SINSABAUGH, R.L., T. WEILAND \& A.E. LINKINS. 1992. Enzymic and molecular analysis of microbial communities associated with lotic particulate organic matter. Freshwat. Biol.. 28: 393-404.

SINSABAUGH, R.L. \& S. FINDLAY, 1995. Microbial production. enzyme activity, and carbon turnover in surface sedirnents of the Hudson River estuary. Microb. Ecol., 30: 127-141.

SRIDHAR. K.R. \& F. BARLOCHER, 1993a. Seasonal changes in microbial colonization of frcsh and dried leaves. Arch. Hydrobiol., 128: 1-12.

SRIDHAR, K.R. \& F. BARLOCHER. 1993b. Aquatic hyphomycetes on leaf litter in and near a stream in Nova Scotia. Canada. Mycol. Res. 97: 1530-1535.

STAHL, D.A.. 1997. Molecular approaches for the measurernent of density, diversity, and phylogeny. In: Manual of environmental microbiology (C.J. HURST, G.R. KNUDSEN. M.J. MCINERNEY, L.D. STETZENBACH \& M.V. WALTER. eds.): 102-1 14. ASM Press. Washington.

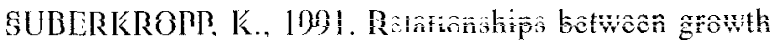
and sporulation of aquatic hyphomycetes on decomposing leaf litter. Mvcol. Res.. 95: 843-8.50.

SUBERKROPP, K., 1992. Interactions with invertebratec. In: The ecology of aquatic hyphomycetes, Ecological Studies, Vol. 94 (F. BARLOCHER, ed.): 118-133. Springer-Verlag. Berlin.

SUHERKROPP, K., 1995. The influence of nutrients on fungal growth, productivity, and sporulation during leaf breakdown in streams. Can. J. Bot. (Suppl. 1): S1361-S1369.

SUBERKROPP, K., 1997. Annual production of leaf decaying fungi in a woodland stream. Freshwat. Biol, 38: 169-178.

SUBERKROPP, K., 1998. Microorganicms and organic matter decomposition. In: River ecology and management: lessons from the Pacific Coastal Ecoregion (R.J. NAIMAN \& R.E. BILBY, eds.): 120-143. Springer-Verlag. New York.

SUBERKROPP, K. \& E. CHAUVET, 1995. Regulation of leaf breakdown by fungi in streams: influences of water chemistry. Ecology, 76: 1433-1445.

SUBERKROPP, K. \& M.J. KLUG, 1976. Fungi and bacteria associated with leaves during processing in a woodland stream. Ecology, 57: 707-7 19.

SUBERKROPP, K.. M.O. GESSNER \& E. CHAUVET, 1993. Comparison of ATP and ergosterol as indicators of fungal biomass associated with decomposing leaves in streamc. Appl. Environ. Microhiol.. 59: 3367-3372.

SUBERKROPP, K. \& H. WEYERS, 1996. Application of fungal and bacterial production methodologies to decomposing leaves in streams. Appl. Environ. Microbiol., 62:1610-1615.

TANK, J.L., J.R. WEBSTER, E.F. BENFIELD \& R.L. SINSABAUGH, 1998. Effect of leaf litter exclusion on microbial enzyme activity associated with wood biofilms in streamc. $J . N$. Am. Benthol. Soc, 17: 95-103.

WEBSTER, J.R., J.B. WALLACE \& E.F. BENFIELD, 1995. Organic processes in streams of the Eactern United Statec. In: Ecosystems of thr world 22, Rivrr and stream ecosystems (C.E. CUSHING, K.W. CUMMINS \& G.W. MINSHALL, eds.): 117 -

187. Elsevier. Amsterdam.

WEIGELHOFER, G. \& J.A. WARINGER, 1994. Allochthonous input of coarse particulate organic matter $(\mathrm{CPOM})$ in a first to fourth order Austrian stream. Int. Rev. ges. Hydrobiol., 79: 461-471.

WEYERS, H.S \& K. SUBERKROPP, 1996. Fungal and bacterial production during the breakdown of yellow poplar leaves in 2 streains. J. N. Am. Benthol. Soc., 15: 408-420. 